\title{
Economy Learning Transfer And Entrepreneurship Among Furniture Industry In Pasuruan Town
}

\author{
Nunuk Indarti \\ (Post Graduate Programs of Universitas Negeri Malang, Indonesia)
}

\begin{abstract}
Achieving success in every entrepreneur has different outcome between the furniture industry and one another. The transfer process occurs in the furniture industry and its influence on the family in Pasuruan town. The goal of this research is to see the difference in the transfer process into three categories of industry leaders such as large, medium, and small. Success furniture industry entrepreneurs are not only from non-formal and informal education but also formal education alone can affect the success of industrial entrepreneur furniture. Some of them affect the success of business furniture industry leaders, they are: 1) the influence of formal education, non-formal and informal experience in achieving business success. The higher the formal education, the higher the level of success is achieved, 2). The works of parents have an influence on the process of the formation of entrepreneurial spirit children, 3). Furniture industry success is on going through with the courage to start a business from an early age and the experience gained by a motivation to be more independent, 4) evaluating business conditions to improve production systems, marketing systems, sales system and bookkeeping systems, 5)having a good cooperative relation with customers and employees and partners are needed. 6). business failures can cause a lack of ability, experience and skills in financial management
\end{abstract}

Keywords: learning economy Transfer, Entrepreneurship, Furniture Industry

\section{INTRODUCTION}

Achieving success in every entrepreneur is different with each other. The success differences is influenced by several indicators, such as: an increase in the accumulation of capital or capital increase, the amount of production, the number of customers, business expansion, marketing expansion, improvement of physical facilities and operating revenues (Dwi Riyanti, (2003). Based on the success indicators which are dictated by Dwi Riyanti (2003), a great example of the furniture industry is UD. Jati Makmur, head of the furniture industry is H.sukandar. Learning from his experience to help his parents, he began to open his own successful business. Today, he can develop his business well with a turnover Rp.2.000.000.000, - it combined workforce about 400 people and production processes mostly use traditional machines for producing furnitures. Bookkeeping in the company also use the system computerization. Meanwhile, an example from the furniture industry is UD. Abi Jaya. This industry leader is Mr. Danang. He opened this business based on personal experiences in his reallife. He is an employee in his uncle furniture industry. This experience can be the inspiration to open his business. Turnover in earn each month to reach Rp. 1,500,000,000, - it combined workforce of about 200 employees and bookkeeping companies use computerized. Example of small furniture producer is from UD. Yasir Jaya. The furniture industry business belonged to Nizar Jaya. It is a legacy to his son Tino pack pack Goni. This bussiness was not founded by him but it continues his parents business. The experienced management who are not good in managing the business, so he is not able to repay the debt when it matures, he has debts exceed its assets, and the imbalance of the capital company by the number Bookkeeping debt receivables in the company by using manually system. The three industries have different backgrounds business establishment, improvement and the accumulation of capital or capital increase, the amount of production, the number of customers, business expansion, marketing expansion areas, physical facilities and operating revenues improvement by each furniture industry business leaders. The background differences are included in the transfer process of education and learning economics. They are different, so the success obtained will produce different results. Economic education is an activity to change people attitudes and behavior in a mature. Business man or also can say as the absorption of knowledge through teaching and training efforts to meet economic or create a means of satisfying human needs are limited. Trianto (2010: 17) states that "Learning is a two-way interaction of a teacher and the learner, in which communication occurs between the two (transfer) the intense and directed toward a target that has been set before."

Then it can be concluded, the learning economy is the process of the interaction of learners and educators and learning resources on environmental economics from family education. Business world environment have an important role for employers. Personal factors values will characterize business in developing entrepreneurs 
where the value will differentiate an entrepreneur with other entrepreneurs. Employers furniture industry can not anticipate the business world environment, may be declining and experiencing financial difficulties will eventually experience bankrupt. Therefore, entrepreneur's furniture industry should be more active in business.

According to Heru S. (2009) proved to entrepreneurship education can make interested and motivated, both could see their opportunities for profitable business (opportunity factor), the third having skills such as social skills, industrial skills, organizational skills and strategic skills. While according Suyanto (2010) deals with the critical success factors of small businesses in the mark by a reflection of the ability of businesses (knowledge, attitudes, and skills), relevance experience, motivation and level of education a businessman.

Winkle (2005: 514) states that " transfer of learning has meaning removal or transfer of learning outcomes which are achieved in the field of study to another study or daily life outside the scope of school education" it is the removal and. Learn transfer is a series of activities and soul to obtain a change in behavior as a result of individual experience in interaction with the environment that includes cognitive, affective and psychomotor.

According Balgwin and Ford which states that the positive transfer of training is the degree to apply the knowledge, skills, and attitude effectively gained in a training context to the job "means that the transfer of training is the activity effectively and sustainably to apply the expertise, skill and an attitude that was obtained from a training.

According to Broad and Newstroom stated that transfer of training is the effective and continuing application, by trainees to Reviews their jobs, of the knowledge and skills gained in training both and off the job "means that the transfer of training to identify the extent to which trainees can apply what you earned of training so as to change the behavior of participants in carrying out their work. Thus it can be concluded that the transfer of training to identify the extent to which trainees can apply what was obtained from the training so as to change the behavior of participants in the execution of their work.

Trianto (2010: 17) states that "learning is a two-way interaction of a teacher and the learner, in which communication occurs between the two (transfer) the intense and directed toward a target that has been set in advance". While purwanto (2011: 185) states "Learning is Organizing resources, facilities and environment to cultivate students' learning activities". According to Wikipedia, states "learning is a process of interaction of learners with learners and learning resources in a learning environment. Learning is a relief that is provided educators to occur the process of acquiring knowledge and learning. Mastery of skills and temperament is as well as the formation of attitudes and beliefs on the learner to be able to run well ". Based on the description above can be concluded that bringing economic learning is the process of the interaction of learners with learning resources educators and economic education in a learning environment.

Entrepreneurship as a profession because the interaction between the knowledge obtained from education and art that can only be replaced from the series of work is given in practice (Mesmudi, 1998). Education Entrepreneurship who is responsible, they argued that entrepreneurship education is a shared responsibility between families, communities and governments, therefore the education lasts a lifetime and be carried out in the family, school and community (Guruvalah, 2003; 1). Entrepreneurship education has been defined as education that aims to create goods and services that can generate higher economic value (Hensemark, 1998; 32). Furthermore Hesenmark reiterated that the main goal is to build entrepreneurial skills, knowledge, and character formation which is important for entrepreneurial activity. Education will increase entrepreneurs with knowledge of the business and formed a psychological attributes such as self-confidence, self-esteem and efficacy self (Kourilsky \& Walstad, 1999). Entrepreneurship education will form self-employment, with increasing knowledge of the business and formed a psychological attributes such as self-confidence, self-esteem and self efficacy (Kourilsky \& Walstad, 1998). It is supported by Kuratno (2003) which asserts that entrepreneurship education should develop negotiating skills, leadership, new product discovery, creative thinking and open technological innovation. Entrepreneur school education aims to develop academic potential and personality of students, master of science and technology, according to the needs and develop world of work. It is strengthened by Tedjasutisna (in Rahayu, 2008) suggests that the purpose of development of entrepreneurship in schools, colleges and communities are as follows: a) Increase the number of qualified entrepreneurs, b). Realizing the capabilities and strengthen entrepreneurs on the production capacity and the welfare of society. c). Cultivating the spirit, attitude, behavior, and Traffic entrepreneurship among students, college students, and the community at large. d). Fostering awareness and formidable entrepreneurial orientation and the students, the community at large

According to Hatton and Raymond (1994) who studied the developing small business organization see the effects of variables to the success of small businesses. Research results show that the environment, the strategy has a positive relationship with business success, where the variable is the most dominant factor of the technology. Studies were done before encourage interested researchers to look at other things that have not been revealed in depth, that reveal how the transfer process of education and learning economics in the furniture industry in Pasuruan town. 


\section{RESEARCH METHOD}

To find out the transfer process of economic and entrepreneurial learning in the furniture industry in Pasuruan town, the researcher use descriptive qualitative method which is employed the phenomenological method (naturalistic). Qualitative research seeks to uncover the symptoms thoroughly and in context through data collection from natural background to avail ourselves of the researcher as the core instrument. Naturalistic here means shows the implementation of this research occurring, in normal circumstances, not to manipulate subject's state and condition, and insists on the natural conditions.

\section{RESULT}

The success of an entrepreneur is not only the furniture industry of informal and non-formal education but formal education also affects the success of an entrepreneur furniture industry. It can affect the success of the business leaders of the furniture industry, namely: 1) the influence of the experience of formal education, non-formal and informal in business success. The higher the formal education, the higher the success achieved 2) the work of the parents has an influence on the process of formation of the soul of entrepreneurships children. 3) The success of the furniture industry is on going through with the courage to start a business from an early age and the experience gained is a motivation to be more independent. 4) Evaluate the condition of the business by improving production systems, marketing systems, sales systems and bookkeeping systems. 5). Develop a working relationship that both customers and employees and partners. 6). Business failure due to lack of skills, experience and skills in financial management.

The findings show that the success of the three leaders of the furniture industries indicate that their important role in an environmental education school (formal), family environment (informal) and the community (non-formal). Effect of higher education to make the level of business success is more developed in comparison with low education. The transfer process in the furniture industry obtain a change of the experience that will be experienced by the industry leaders and then apply what is obtained in the business. In starting his business as well as continuing efforts of his parents, leaders of the furniture industry have educational experience in schools to get the theory of entrepreneurship, education in the family environment to gain practical experience of learning directly from parents to their children and surrounding communities that support because most are the furniture industry. Thus it can motivate and can form the entrepreneurial spirit of a child from an early age.

\section{CONCLUSION}

Based on the focus of the problem, the results of the analysis to the three furniture industry it can be concluded that the economic and entrepreneurial education is equally obtained from the parents. The learning experience in leadership in the industry was gained through formal education, non-formal and informal. Education starts from the family who has an important role in the development of furniture business industry. Parents have a duty as educators to inculcate attitudes, behaviors and values because it formed life skills. Friend has a great role and influence in education, because a friend is able to establish the principles and understanding that can not do both parents.

\section{REFERENCES}

[1] Bransford, J.D., Brown,A.L.,\&Cocking, R. R. 2000.How people learn: Brain, mind,experient, and school.Washington,DC: National Academy Press.

[2] Benedicta prihatin Dwi, Riyanti.,2003.Kewirausahaan Dari Sudut Pandang Psikologi Kepribadian.Jakarta: Grasindo.

[3] Craig,L.Shannon., 1999.Transfer Training.Seminar In Industrial Psychology. September 29. (Online).www.Geocities.Com./rpipsych/tran

[4] Darling-Hammond, L., \& Bransford,J.D.,2005. Preparing teachers for achanging world: what teachers should learn and be able to do.San Fransisco,CA:Jossey-bass.

[5] Dale Yoder., 2000 "Personal Manajemen and Industrial Relation" New Delhi

[6] Gagne,Robert.M.(1985).The conditions of learning and theory of instruction (4th ed). New York, NY: Holt, Rinehard \&Winston.

[7] Djumransjah,H.M.2004. Pengantar Filsafat Pendidikan. Malang. Bayumedia Publishing.

[8] Gilkey, R.et al., 1985. Definisi Teknologi Pendidikan. Diterjemahkan oleh Yusufhadi Miharso dkk.Jakarta:Rajawali.

[9] Guruvalah.,2003. Kepala Sekolah $\quad$ sebagai $\quad$ Wirausaha.http://WWW geocities.Com/Guruvalah/entrepreneur kepsek.html.diakses tanggal 5 Oktober 2015.

[10] Hansemark, O. 1998. The Effects Of An Entrepreneurship Programme On Need Forachievement And Locus of Control Of Reinforcement. International Journal Of Entrepreneuship Behaviour and research, $4(1): 28-50$ 
[11] Hisrich, RD.dan Peter,MP.2005.Entrepreneurship, Starting, Developing and Managing A New Enterprise Chicago:Richard Dirwin,inc.

[12] Kourilsky, M. L., \& W. B.1998. Entrepreneurship And Female Youth: Knowledge, Attitudes, Gender Differences, And Educational Prectices. Journal of Business Venturing, 13(1): 77-78. (Online), (http://www.Jurnal.internasional.com) pdf, diakses tanggal 6 Oktober 2015

[13] Kuratno, Donald and Hodgeetts, Richard (2007). Entrepreneurship Theory, Process and Practice, seven edition, Thomson South -Western.Canada

[14] Mesmudi,PD.1998. Arti Dan Pentingnya Wirausaha. Makalah. Disajikan dalam Diklat Kewirausahaan bagi Mahasiswa dilingkungan UNEJ. (Online),(http://www,Jurnal.internasional.com) pdf, diakses tanggal 5 Oktober 2015.

[15] Moekijat, 2005 Dasar-dasar Motivasi,. Sumur Bandung, Bandung

[16] McClelland, D.1967.The Achieving Society.Bombay India: peffer \& Simon (Online), (http://www.Jurnal.internasional.com) pdf, diakses tanggal 29 September 2015

[17] Mangkunegara, A.A.A.P 2003 Perencanaan dan Pengembangan Sumber Daya Manusia. Bandung, Refika Aditama.

[18] McClelland, David C. (1961). Entrepreneur Behavior and Characteeristics of Entrepreneurs. (Online), (http://www.Jurnal internasional) pdf, diakses tanggal 29 September 2015.

[19] McKeough, A. (1995). Teaching for transfer: Fostering generalization in learning. Mahwah, NJ: Lawrence Erlbaum. (Online). (http://www.transferbelajar.com) pdf, diakses tanggal 29 September 2015

[20] Purwanto,2011.Evaluasi Hasil Belajar.Yogyakarta:Pustaka Pelajar

[21] Tarigan, Robinson.2006. Pengaruh Tingkat Pendidikan Terhadap Tingkat Pendapatan Perbandingan Antara Empat Hasil Penelitian.

[22] Tarigan, Robinson.2004.Perencanaan Dan Pembangunan Sumber Daya Manusia Bandung, Refika Aditama.

[23] Samuelson,Nordhaus.2005. Economics 18th Edition.New York: MC Graw Hill-Irwin

[24] Schunk, D.H.2004. Learning Theories: An educational Perspective.Upper Saddle River, NJ:Pearson.

[25] Soemanto. Wasty (1998) Psikologi Pendidikan Jakarta :Rineka Cipta.

[26] Sudjana. 2011. Dasar-dasar Proses Belajar Mengajar .Bandung Sinar baru. Algensindo.

[27] Sagir,N.S. 1989. Membangun Manusia Karya-Masalah Ketenagakerjaan dan Pengembangan Sumber Daya Manusia.Jakarta,Pustaka Sinar Harapan.

[28] Trianto, 2007. Model-model pembelajaran Inovatif Berorientasi

[29] Woolfolk, A. 2010. Educational psychology (11th ed).Upper Saddle River, NJ:Merrill.

[30] Winkel,w.s. 2007.Psikologi Pengajaran Yogyakarta, Media Abadi. 